\title{
Technical and agronomic efficiency of oat cultivars as a function of nitrogen availability
}

\section{Eficiência técnica e agronômica de cultivares de aveia em função da disponibilidade de nitrogênio}

\section{Emilio Ghisleni ARENHARDT ${ }^{1}$; José Antonio Gonzalez da SILVA ${ }^{2}$; Lorenzo Ghisleni ARENHARDT ${ }^{3}$; Dionatas Rodrigues da SILVA ${ }^{3}$; Maria Eduarda GZERGORCZICK ${ }^{3}$; Guilherme Paim CEOLIN ${ }^{4}$; Cristiano STÜLP ${ }^{4}$; Ricardo Garcia FIGUEIREDO ${ }^{4}$; Antonio Costa de OLIVEIRA ${ }^{5}$}

\begin{abstract}
${ }^{1}$ Autor para correspondência. Msc, Doutorando em Melhoramento e Biotecnologia Vegetal, Departamento de Fitotecnia, Universidade Federal do Rio Grande do Sul (UFRGS). Avenida Bento Gonçalves, 7712, Bairro Agronomia, Porto Alegre, RS, Brasil.emilio.arenhardt@yahoo.com.br

${ }^{2}$ Dr. Professor do Departamento de Estudos Agrários, Universidade Regional do Noroeste do Estado do Rio Grande do Sul (UNIJUÍ), Rua do Comércio, 3000, Bairro Universitário, ljuí, RS, Brasil. jagsfaem@yahoo.com.br

3 Bolsista de Iniciação Científica/CNPq do Curso de Agronomia da Universidade Regional do Noroeste do Estado do Rio Grande do Sul (UNIJUÍ), Rua do Comércio, 3000, Bairro Universitário, ljuí, RS. lorenzoarenhardt@gmail.com; dionatas_rodrigues16@hotmail.com; eduardagze@gmail.com

${ }^{4}$ Bolsista de Iniciação Científica/CNPq, Departamento de Fitotecnia, Faculdade de Agronomia "Eliseu Maciel", Universidade Federal de Pelotas, Capão do Leão,RS. guilhermepceolin@gmail.com, cristiano_stulp@hotmail.com, ricardogf91@hotmail.com

${ }^{5} \mathrm{PhD}$. Professor do Departamento de Fitotecnia, Faculdade de Agronomia "Eliseu Maciel", Universidade Federal de Pelotas, Capão do Leão,RS. acostol@gmail.com
\end{abstract}

Recebido em: 06-03-2017; Aceito em: 11-05-2017

\begin{abstract}
Nitrogen, while favoring oat grain yields, can bring enormous losses by lodging. The aims of the study were to evaluate the productive performance of oat cultivars the susceptible and resistant to lodging under conditions of reduced, high and very high availability of nitrogen; estimate the technical and agronomic efficiency of cultivars, according to the ideal nitrogen dose, for grain yield and lodging predictability; to verify if oat cultivars with higher nutrient use efficiency for grain yield are more lodging prone, to have applicability in breeding programs. The study was conducted in 2013 and 2014 in Capão do Leão and Augusto Pestana, RS, Brazil. The experimental design was a randomized block with four replications, in a $3 \times 8$ factorial, being the factors evaluated the nitrogen doses and oat cultivars (resistant and susceptible to lodging). The cultivars belonging to lodging susceptible group showed higher grain yields when compared to the resistant group. FAEM Carlasul and URS Corona cultivars, from the lodging susceptible group, showed high technical and agronomic efficiency of grain yield in response to nitrogen, with high lodging at the ideal nutrient dose for grain yield. Crosses between the FAEM Carlasul and Brisasul cultivars can generate high potential genotypes regarding nitrogen use efficiency and stem resistance.
\end{abstract}

Additional keywords: Avena sativa L.; grain yield; lodging; stem resistance.

\section{Resumo}

O nitrogênio, embora favoreça a produtividade de grãos de aveia, pode trazer enormes prejuízos pelo acamamento da planta. Os objetivos do estudo são avaliar o desempenho produtivo de cultivares de aveia suscetíveis e resistentes ao acamamento, em condições de reduzida, alta e muito alta disponibilidade de nitrogênio; estimar a eficiência técnica e agronômica das cultivares, segundo a dose ideal de nitrogênio, para produtividade de grãos e previsibilidade de acamamento; e verificar se cultivares de aveia com maior eficiência no uso do nutriente para produtividade de grãos também detêm maior facilidade ao acamamento, com vista a programas de melhoramento. O estudo foi conduzido em 2013 e 2014, em Capão do Leão e Augusto Pestana, RS, Brasil. O delineamento foi de blocos ao acaso, com quatro repetições, em fatorial $3 \times 8$, sendo avaliados os fatores dose de nitrogênio e cultivares de aveia (resistentes e suscetíveis ao acamamento). $O$ desempenho do grupo de cultivares suscetível ao acamamento evidenciou resultados mais expressivos de produtividade de grãos em comparação ao grupo resistente. As cultivares FAEM Carlasul e URS Corona, do grupo suscetível ao acamamento, mostraram elevada eficiência técnica e agronômica de produtividade de grãos pelo nitrogênio, com elevado acamamento na dose ideal do nutriente à produção de grãos. Cruzamentos entre as cultivares FAEM Carlasul e Brisasul podem gerar populações promissoras na recuperação de cultivares eficientes no uso de nitrogênio com resistência do colmo.

Palavras-chave adicionais: acamamento; Avena sativa L.; produtividade de grãos; resistência do colmo. 


\section{Introduction}

White oats represent in Southern Brazil, a multipurpose crop, with major use in food and feed nutrition (Hawerroth et al., 2015). The expression of oat yield potential is associated to genetic features of cultivars, climate conditions and management techniques (Silva et al., 2012). Regarding management, the new oat biotypes are responsive to nitrogen use, impacting directly on the yield indicators (Mantai et al., 2016). Therefore, the development and recommendation of higher yielding cultivars, tolerant to environmental conditions and light and nutrient use efficient must be sought (Freo et al., 2011, Viola et al., 2013).

In wheat (Flores et al., 2012) and oats (Mantai et al., 2015), the increase in the dose and correct time of application of $\mathrm{N}$-fertilizer, added to favorable environmental conditions, promote a better nutrient use efficiency, with a significant increase in yield. However, in unfavorable years, $\mathrm{N}$ use efficiency is compromised, leading to yield decreases, increase in production risks and environmental pollution (Benin et al., 2012, Silva et al., 2015). Also, N-fertilizer doses can be raised expecting higher yields, but this induces plant lodging, difficulting harvesting and decreasing yields (Flores et al., 2012, Berry et al., 2015, Silva et al., 2016). Lodging is a phenomenum in which the plant loses its vertical position, bends and falls on the soil, resulting in curved plants or even broken stems, affecting yield (Silva et al., 2012, Hawerroth et al., 2015). Severe lodging prevents adequate water transport, nutrient uptake and carbohydrate assimilation via xylem and phloem, resulting in reduced grain filling, with direct negative reflex in yield and quality (Wu et al., 2012).

In order to guarantee simultaneously food security and cultivation sustainability, recommendation of oat cultivars with higher nitrogen use efficiency and reduced lodging is decisive to attain high grain yield and grain quality (Silva et al., 2016, Marolli et al., 2017). In this sense, the characterization of oat cultivars with high technical and agronomic efficiency in the use of nitrogen, high yield and low lodging, represents a qualified strategy in cultivar recommendation.
Agronomic efficiency consists in the association between $\mathrm{N}$ use and product (yield) generation (Moll et al., 1982) and the technical efficiency consists in the association between the ideal $\mathrm{N}$ input and the maximal product expression (Silva et al., 2016). High N efficient oat cultivars are those that respond with high yields with less N (Arenhardt, et al., 2017). However, technical and agronomical efficiency studies are essential for better fertilizer dose recommendation to farmers, aiming at sustainable and more environment friendly production. Also, it allows the identification of more efficient cultivars for use in plant breeding, focusing in the development of more sustainable cultivars by reducing $\mathrm{N}$-fertilizer needs and high yield. In this sense, nitrogen fertilizer should be highlighted not only because its importance and high production cost, but by its efficient use, guaranteeing yield and sustainability (Costa et al., 2013, Mantai et al., 2015).

The objectives of this study were to evaluate the yield performance of lodging sensitive and resistant oat cultivars under reduced, high and very high nitrogen availability; to estimate the technical and agronomical efficiency of cultivars, according to the ideal nitrogen dose in predicting yield and lodging; to verify if oat cultivars with high nitrogen use efficiency also tend to lodge with greater ease, in order to facilitate the selection of superior genotypes.

\section{Material and methods}

In the agricultural years of 2013 and 2014, eight elite oat cultivars recommended for cultivation in Brazil were sown. These genotypes originated in breeding programs and are described either as lodging resistant (Brisasul, URS FapaSlava, UPFA Ouro and URS Taura) or susceptible (FAEM Carlasul, URS Corona, URS Guria and IAC 7). The cultivars were selected according the high grain yield potential and lodging resistance/susceptibility, from the essays performed by the Brazilian Oat Research Committee (CBPA), composed of results from 18 locations per year between 2008 and 2012. The pedigree and the obtainer of each cultivar are presented in Table 1.

Table 1 - Pedigree and obtainer for the white oat cultivars and its respective lodging response group.

\begin{tabular}{|c|c|c|c|}
\hline Group & Cultivar & Obtainer & Pedigree \\
\hline \multirow{4}{*}{ 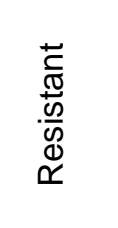 } & Brisasul & UFPEL & OR 2/UPF 18 \\
\hline & URS Taura & UFRGS & UFRGS 970216-2/UFRGS 970461 \\
\hline & URS FapaSlava & UFRGS/FAPA & UFRGS 984111-4/UFRGS 988109-1 \\
\hline & UPFA Ouro & UPF & UPF 16/UPF 18 \\
\hline \multirow{4}{*}{ 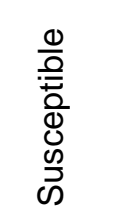 } & FAEM Carlasul & UFPEL & UFRGS 10/90 SAT-285 \\
\hline & URS Corona & UFRGS & UFRGS 987016-1/UFRGS 970497-1 \\
\hline & URS Guria & UFRGS & UFRGS 987015-2/UFRGS 960195-2 \\
\hline & IAC 7 & IAC & V155, ML-IICV-77-CV78-R78-79CV-79-CV80 \\
\hline
\end{tabular}

Source: Adapted from Marangoni et al. (2012). 
The experiments were conducted in the cities of Augusto Pestana - RS, latitude $28^{\circ} 27^{\prime} \mathrm{S}$, longitude $53^{\circ} 54^{\prime} \mathrm{W}, 280 \mathrm{~m}$ altitude, soil classified as Oxisol (Embrapa, 2006) and Capão do Leão - RS, latitude $31^{\circ} 45^{\prime} \mathrm{S}$, longitude $52^{\circ} 29^{\prime} \mathrm{W}, 13 \mathrm{~m}$ altitude, soil classified as Oxyaquic Udifluventes (Embrapa, 2006). Before seeding, a soil analysis was performed and the following were obtained in average: i) Augusto Pestana: (Clay $=420 \mathrm{~g} \mathrm{~kg}^{-1} ; \mathrm{OM}=3.4 \% ; \mathrm{pH}=6.5$; $\mathrm{P}=20.8 \mathrm{mg} \mathrm{dm}^{-3} ; \mathrm{K}=244.7 \mathrm{mg} \mathrm{dm}^{-3} ; \mathrm{Al}=0 \mathrm{cmol}_{\mathrm{c}} \mathrm{dm}^{-3} ;$ $\mathrm{Ca}=6.3 \mathrm{cmol}_{\mathrm{c}} \mathrm{dm}^{-3}$ and $\mathrm{Mg}=2.5 \mathrm{cmol}_{\mathrm{c}} \mathrm{dm}^{-3}$ ) and; Capão do Leão: (Clay $=210 \mathrm{~g} \mathrm{~kg}^{-1} ; \mathrm{OM}=2,1 \%$; $\mathrm{pH}=6.0 ; \quad \mathrm{P}=22.1 \mathrm{mg} \mathrm{dm}^{-3} ; \quad \mathrm{K}=120.0 \mathrm{mg} \mathrm{dm}^{-3}$; $\mathrm{Al}=0.2 \mathrm{cmol}_{\mathrm{c}} \mathrm{dm}^{-3} ; \quad \mathrm{Ca}=3.2 \mathrm{cmol}_{\mathrm{c}} \mathrm{dm}^{-3} \quad$ and $\mathrm{Mg}=2.1 \mathrm{cmol}_{\mathrm{c}} \mathrm{dm}^{-3}$ ). Soil preparation followed the recommendations of the Brazilian Oat Research Committee (CBPA), with NPK as a function of the chemical analysis values for each year and location. According to the needs, tebuconazole fungicide applications were performed, at the dose of $0.75 \mathrm{~L} \mathrm{ha}^{-1}$. Weed control was performed with metsulfuron-methyl at the dose of $4 \mathrm{~g} \mathrm{ha}^{-1}$ plus manual weeding.

All the essays were conducted in random blocks with four replications, according to a $3 \times 8$ factorial model for nitrogen doses and oat cultivars, making a total of 96 plots per location per year. Nitrogen doses used were low $\left(30 \mathrm{~kg} \mathrm{ha}^{-1}\right)$, high $\left(90 \mathrm{~kg} \mathrm{ha}^{-1}\right)$ and very high (150 kg ha-1). The eight oat cultivars represent lodging tolerant and susceptible genotypes, as described on table 1 . Seeds from each cultivar were evaluated in a germination test and ajusted at sowing for the final stand of 350 viable seeds per square meter. Each experimental unit was formed by five lines $5.0 \mathrm{~m}$ long, spaced $0.20 \mathrm{~m}$, with the sampling unit consisting of the three inner rows $\left(3.0 \mathrm{~m}^{2}\right)$.

Grain harvesting was performed manually, the plants threshed with a stationary thresher and sent to the lab for humidity correction to $13 \%$ and weight for yield estimation, converted to $\mathrm{kg}$ per ha.

Lodging (L) was estimated visually before the harvesting and expressed in percentage, considering the angle formed between the stem and the soil surface and the area of lodged plants. For this estimate, a modified method of Moes \& Stobbe (1991) was used. Lodging $(L)$ was defined as: $L(\%)=I \times A \times 2$, in which: $I$ is the degree of plant bending, ranging from 0 to 5 , being 0 the absence of bending and 5 all plants completely lodged; A, representing the area of lodged plants in the plot, which can range from 0 to 10 , being 0 the absence of lodged plants and 10 all the plants in the plot lodged, independent of the degree of bending. Therefore, this equation balances the incidence and severity of lodging.

Bartlett and Lillifors tests were performed to analyze the data homogeneity and normality assumptions. Thereafter, an analysis of variance was performed to detect the main effects of dose, year and cultivar, as well as their interactions. Based on the average performance of cultivars in the set of environments, a mean clustering test was performed using Scott \& Knott's test (1974) at $P \leq 0.05$. The variation sources cultivar and nitrogen doses were defined as fixed effects. Later, a fitting test for first degree regression for the analysis of maximal agronomic efficiency and point interpolation between 60 and $120 \mathrm{~kg} \mathrm{~N} \mathrm{ha}^{-1}$. After, a fitting test for a second degree regression was performed to measure the maximal technical efficiency for nitrogen to grain yield and the simulation of lodging using the ideal nitrogen dose for grain yield. The analyses were performed using the GENES (Cruz, 2013) software.

\section{Results and discussions}

The variation sources year, dose and cultivar significantly altered lodging and grain yield (Table 2). Independently from the location, a triple interaction was also significant, indicating a strong interactivity between year and nitrogen dose in the expression of lodging and grain yield. Therefore, it was necessary to partition this interaction into simple effects.

In Figure 1, rain and temperature data, independent from location, indicate 2013 as a favorable year, especially because of adequate rain volumes, both before the $\mathrm{N}$ fertilization, as well as during the course of cultivation. In Augusto Pestana, in 2014, there were heavy rains, both at the beginning of cultivation, limiting plant growth, as well as at the end of the cycle, at the physiological maturation and harvesting point, limiting grain filling and grain quality. In Capão do Leão, 2014 did also presented high rain volume at the beginning of development, vegetative cycle and grain filling stages, limiting grain yield.

The distinct performance of white oat cultivars in response to environmental changes are commonly observed in Southern Brazilian conditions, for many traits of agronomic importance (Carvalho et al., 2009, Crestani et al., 2010). Thus, the characterization of elite white oat cultivars under distinct cultivating environments allows a better estimation of genetic potential and available variability (Crestani et al., 2010). Cordeiro et al. (2015) reported that the climate is a strong fator influencing yield, which requires regions with low temperatures and adequate distribution of rains with low intensity. Excess rain before and after fertilization causes damages to the plant because it causes oxigen levels to drop and also can cause nutrient loss due to leaching (Ercoli et al., 2013). High temperatures also promote yield drops due to nitrogen loss by volatilization and biomass accumulation reduction due to the increase in respiration rates. This condition can lead to decreases in carbon sequestering, contributing to global warming (Mandal et al., 2016). Temperature and rain are meteorological variables used to rank favorable and unfavorable years, regarding cereal cultivation (Arenhardt et al., 2015, Mantai et al., 2016). 
Table 2 - Summary of the analysis of variance for nitrogen use in oat cultivars in the years and cultivation locations.

\begin{tabular}{|c|c|c|c|}
\hline \multirow{2}{*}{ Variation Source } & \multirow{2}{*}{ D.F. } & \multicolumn{2}{|c|}{ Mean Square } \\
\hline & & Lodging & Grain Yield \\
\hline & & \multicolumn{2}{|c|}{ Capão do Leão, RS } \\
\hline Block & 3 & 164 & 210420 \\
\hline Year (Y) & 1 & $7056^{*}$ & $227631^{*}$ \\
\hline Dose (D) & 2 & $35311^{*}$ & $1320142^{*}$ \\
\hline Cultivar (C) & 7 & $8811^{*}$ & $3327182^{*}$ \\
\hline$A \times D$ & 2 & $1597^{*}$ & $1283909^{*}$ \\
\hline$A \times C$ & 7 & $348^{*}$ & $572926^{*}$ \\
\hline$D \times C$ & 14 & $1001^{*}$ & $180474^{*}$ \\
\hline$A \times D \times C$ & 14 & $581^{*}$ & $171966^{*}$ \\
\hline Error & 141 & 49 & 80923 \\
\hline Total & 191 & & \\
\hline General Mean & & 40 & 2213 \\
\hline \multicolumn{2}{|l|}{ C.V. (\%) } & 17.3 & 12.8 \\
\hline & & \multicolumn{2}{|c|}{ Augusto Pestana, RS } \\
\hline Block & 3 & 49 & 150007 \\
\hline Year (Y) & 1 & $11056^{*}$ & $134975022^{*}$ \\
\hline Dose (D) & 2 & $46400^{*}$ & $1731742^{*}$ \\
\hline Cultivar (C) & 7 & $10948^{*}$ & $2285375^{\star}$ \\
\hline$A \times D$ & 2 & $887^{*}$ & $21346^{\text {ns }}$ \\
\hline$A \times C$ & 7 & $1523^{*}$ & $617764^{*}$ \\
\hline$D \times C$ & 14 & $1736^{*}$ & 99373* \\
\hline$A \times D \times C$ & 14 & $261^{*}$ & $59018^{*}$ \\
\hline Error & 141 & 39 & 47917 \\
\hline Total & 191 & & \\
\hline General Mean & & 39 & 1915 \\
\hline C.V. $(\%)$ & & 15.8 & 11.4 \\
\hline
\end{tabular}

* Significant at $P \leq 0.05$ by the $F$ test; ${ }^{n}$ - Non significant at $P \leq 0.05$ by the $F$ test; D.F.- Degrees of freedom; C.V. - Coefficient of variation.

In Capão do Leão in 2013, the reduced nitrogen condition contributed very little for lodging, even though the majority of cultivars from the resistant group exhibited lower lodging values (Table 3). The $90 \mathrm{~kg} \mathrm{ha}^{-1}$ dose was effective in favoring plant lodging, allowing an easy differentiation between groups of cultivars. The higher nitrogen dose favored lodging in the majority of cultivars, independent from the group. The cultivar URS Taura was the best genotype, showing low lodging. In 2014, in Capão do Leão, lodging was observed in the lowest dose, especially for the susceptible cultivars, showing a more pronounced effect as the dose was increasing (Table 3). A differentiation of cultivars was obtained in the three fertilizer doses, but better seen in the highest nitrogen dose. In Augusto Pestana, in 2013, distinct lodging was not detected between cultivars from the resistant and susceptible groups in the lowest nitrogen dose. On the other hand, the highest dose, with $90 \mathrm{~kg} \mathrm{ha}^{-1} \mathrm{~N}$, promoted lodging and the discrimination between resistant and susceptible groups, except for UPFA Ouro, from the resistant group, that presented similar performance to the susceptible cultivars. This tendency was also observed for the very high $\mathrm{N}$ dose $\left(150 \mathrm{~kg} \mathrm{ha}^{-1}\right)$, in this cultivar. Therefore, an intermediate performance was observed on the expression and instability of the character since GxE was observed. In 2014, both at 90 and $150 \mathrm{~kg} \mathrm{ha}^{-1} \mathrm{~N}$, a difference of groups regarding resistance was seen. In these doses, the cultivars Brisasul, URS Taura and URS FapaSlava, from the resistant group, presented the most reduced lodging values. Either in Capão do Leão or Augusto Pestana, the definition of nitrogen dose for the characterization of resistant and susceptible cultivars to lodging is dependent from year and applied $\mathrm{N}$ dose. 
2013 - Capão do Leão, RS

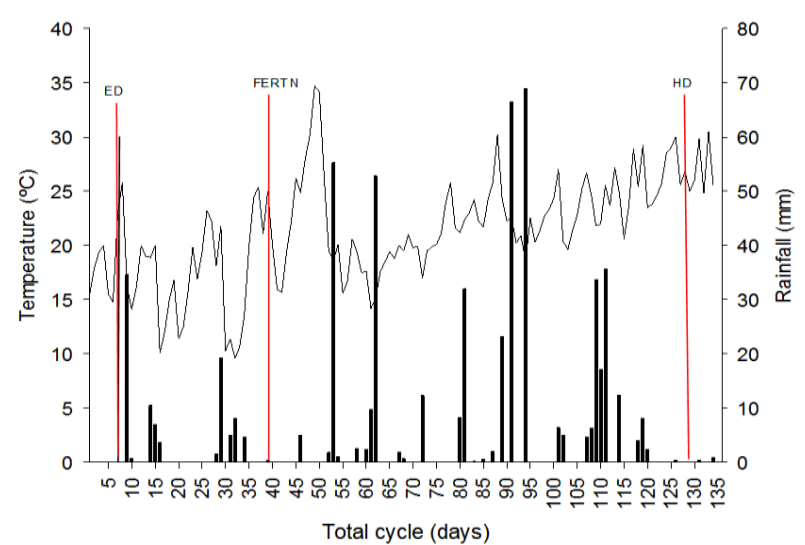

2014 - Capăo do Leão, RS

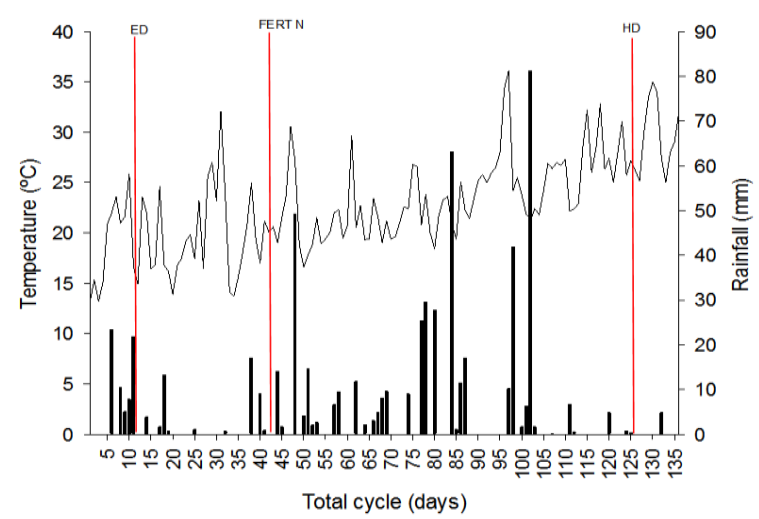

2013 - Augusto Pestana, RS

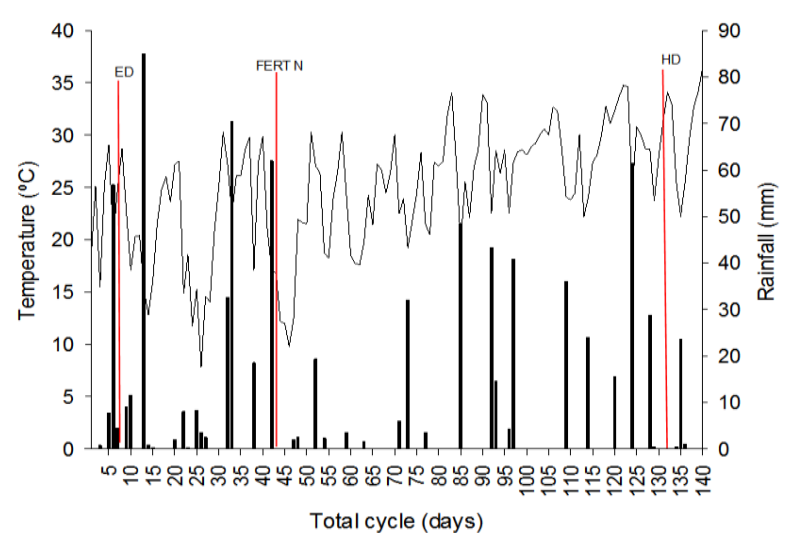

2014 - Augusto Pestana, RS

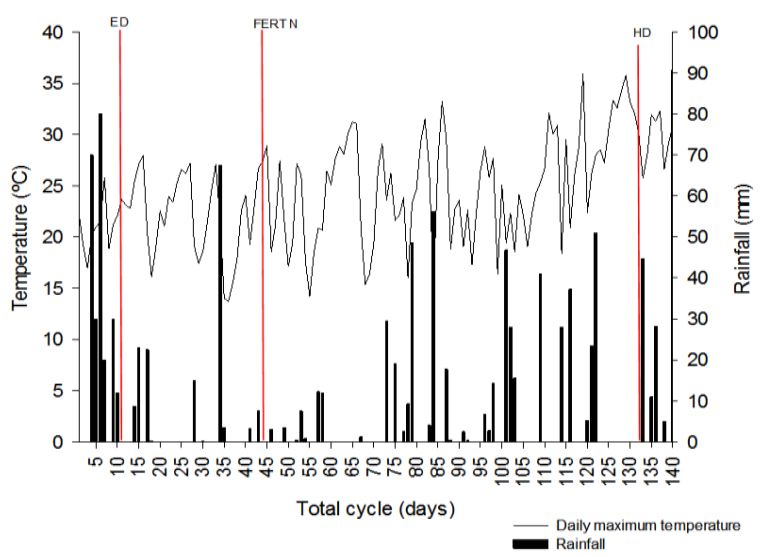

Figure 1 - Rainfall data and maximum temperature in the different years and cultivation fields. $\mathrm{ED}=$ Emergency day; FERT $\mathrm{N}=$ Nitrogen fertilization at 30 days after emergence; $\mathrm{HD}=$ Harvest day. Source: Agroclimatological Station of Pelotas/Embrapa Temperate Climate (Capão do Leão); Regional Institute for Rural Development//RDeR/UNIJUÍ (Augusto Pestana). Sowing date: Augusto Pestana $=10 / 07 / 2013$ and 25/07/2014; Capão do Leão = 25/07/2013 and 29/07/2014 .

In Capão do Leão, in 2013 (Table 3), higher grain yields were detected in a larger group of susceptible genotypes, both at 30 and $90 \mathrm{~kg} \mathrm{ha}^{-1}$ of $\mathrm{N}$-fertilizer. At the very high $\mathrm{N}$ dose $\left(150 \mathrm{~kg} \mathrm{ha}^{-1}\right)$, the number of cultivars with high performance for grain yield was similar when the resistant and susceptible groups were compared. In general, cultivars from the susceptible group expressed similar or higher grain yield than the resistant group at different $\mathrm{N}$ supplying doses. URS Corona, a susceptible cultivar, did perform better in all fertilizer doses. In 2014, at the $\mathrm{N}$ dose of $30 \mathrm{~kg} \mathrm{ha}^{-1}$, the majority of cultivars displaying higher yields belonged to the susceptible group. At the $\mathrm{N}$ doses of 90 and $150 \mathrm{~kg} \mathrm{ha}^{-1}$, the number of resistant and susceptible cultivars displaying higher yields was similar. The cultivar URS Guria, from the susceptible group, displayed higher grain yield at the distinct $\mathrm{N}$-fertilizer doses.

In Augusto Pestana, in 2013 (Table 3), similarity for grain yield was observed at the reduced $\mathrm{N}$ dose, independing from lodging expression group. In general, the doses of 90 and $150 \mathrm{~kg} \mathrm{ha}^{-1}$ did show higher grain yields for the cultivars Brisasul and URS Taura, from the resistant group, and FAEM Carlasul and URS Guria, from the susceptible group. In 2014, the reduced, high and very high doses translated into higher yields in the cultivars Brisasul and UPFA Ouro, from the resistant group, and FAEM Carlasul and URS Corona, from the susceptible group. These results indicate a high performance per se of these cultivars under different nitrogen conditions and the presence of independent genes that act on grain yield and lodging resistance. Therefore, cultivars from the susceptible group can bring a large contribution of favorable alleles controlling grain yield. The strong expression of grain yield in Augusto Pestana is also dependent on the cultivation year, reporting the need to develop nitrogen responsive and low lodging cultivars, as well as presenting genes for yield stability facing constant climatic changes. The reduced grain yield performance and high lodging of the cultivar IAC 7, indicates a nonadapted cultivar, independent from year and location. 
Table 3 - Means of lodging and grain yield in the lodging groups by the nitrogen use in the years and cultivation fields.

\begin{tabular}{|c|c|c|c|c|c|c|c|}
\hline \multirow{2}{*}{ Group } & \multirow{2}{*}{ Cultivar } & \multicolumn{3}{|c|}{ Lodging (\%) } & \multicolumn{3}{|c|}{ Grain Yield $\left(\mathrm{kg} \mathrm{ha}^{-1}\right)$} \\
\hline & & $30^{+}$ & 90 & 150 & 30 & 90 & 150 \\
\hline \multirow{7}{*}{ 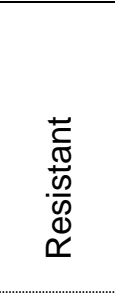 } & & \multicolumn{6}{|c|}{ Capão do Leão, RS } \\
\hline & & \multicolumn{6}{|c|}{ Year 2013} \\
\hline & Brisasul & B $1.5 \mathrm{~b}$ & B $6.8 \mathrm{c}$ & A $50.0 \mathrm{c}$ & A 2492 a & A 2828 b & A 2781 a \\
\hline & URS Taura & A $1.3 b$ & A $6.8 \mathrm{c}$ & A $9.8 \mathrm{e}$ & B $1676 \mathrm{~b}$ & A 1985 C & A 2238 a \\
\hline & URS FapaSlava & B 3.5 b & B $5.0 \mathrm{c}$ & A $28.8 d$ & B $1377 \mathrm{~b}$ & A 1898 C & B 1155 C \\
\hline & & B $15.0 \mathrm{a}$ & B $13.8 \mathrm{c}$ & A $60.0 \mathrm{~b}$ & B 2064 a & A 2768 b & A $2530 \mathrm{a}$ \\
\hline & Mean & 5.3 & 8.1 & 37.2 & 1902 & 2370 & 2176 \\
\hline \multirow{5}{*}{ 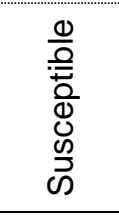 } & И Carlasul & B 9.8 a & A $65.0 \mathrm{a}$ & A $67.5 \mathrm{~b}$ & B 2205 a & B 2293 C & A 2726 a \\
\hline & URS & C $10.5 \mathrm{a}$ & B $53.8 \mathrm{~b}$ & A 90.0 a & C 2329 a & A 3401 a & B 2837 a \\
\hline & URS C & $13.0 \mathrm{a}$ & B $52.5 \mathrm{~b}$ & A $87.5 \mathrm{a}$ & B 1923 a & A 2702 b & A 2659 a \\
\hline & IAC 7 & C $14.3 \mathrm{a}$ & B $73.8 \mathrm{a}$ & A 96.3 a & A $1513 b$ & A 1853 C & A $1722 b$ \\
\hline & Mean & 11.9 & 61.3 & 85.3 & 1993 & 2562 & 2486 \\
\hline \multirow{6}{*}{$\begin{array}{l}\frac{}{c} \\
\frac{\pi}{w} \\
\frac{w}{w} \\
0 \\
\simeq\end{array}$} & & \multicolumn{6}{|c|}{ Year 2014} \\
\hline & Brisasul & B $9.3 \mathrm{~d}$ & A $31.3 d$ & A 32.5 c & A 2318 a & A 2361 a & A 2224 b \\
\hline & URS 1 & C $12.5 \mathrm{~d}$ & B $26.3 d$ & A 53.8 b & A 2216 a & A 2277 a & A $2317 \mathrm{~b}$ \\
\hline & URS FapaSlava & B $8.0 \mathrm{~d}$ & A $43.8 \mathrm{c}$ & A 32.5 c & A $1869 b$ & A 1917 a & A 1954 C \\
\hline & UPFA Ou & B $22.5 \mathrm{C}$ & A $57.5 \mathrm{~b}$ & A $47.5 \mathrm{~b}$ & B 2024 b & A 2393 a & A 2645 a \\
\hline & Mean & 13.1 & 39.7 & 41.6 & 2107 & 2237 & 2285 \\
\hline \multirow{7}{*}{$\begin{array}{l}\frac{0}{0} \\
\frac{0}{\overline{0}} \\
0 \\
0 \\
0 \\
0 \\
\omega\end{array}$} & FAEM Carlasul & B $33.8 \mathrm{~b}$ & A $75.0 \mathrm{a}$ & A $76.3 \mathrm{a}$ & A 2292 a & A 2247 a & A $2439 \mathrm{~b}$ \\
\hline & & C $21.3 \mathrm{c}$ & B 46.3 c & A 85.0 a & A 2446 a & A 2282 a & A $2361 \mathrm{~b}$ \\
\hline & URS Guria & B $27.5 \mathrm{~b}$ & A 86.3 a & A 83.8 a & A 2460 a & B 1991 a & A 2733 a \\
\hline & IAC 7 & B $45.0 \mathrm{a}$ & A 80.0 a & A 89.5 a & A $1570 \mathrm{~b}$ & A $1356 b$ & A 1712 C \\
\hline & Mean & 31.9 & 71.9 & 83.7 & 2192 & 1969 & 2311 \\
\hline & & \multicolumn{6}{|c|}{ Augusto Pestana, RS } \\
\hline & & & & & & & \\
\hline \multirow{5}{*}{ 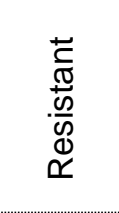 } & Brisasul & B $1.3 \mathrm{a}$ & B $2.5 \mathrm{C}$ & A $16.3 d$ & B 2525 a & A 3139 a & A 2889 a \\
\hline & & B $1.8 \mathrm{a}$ & B 5.0 c & A $15.0 \mathrm{~d}$ & B 2424 a & A 3049 a & A 3084 a \\
\hline & URS FapaSlava & B $1.5 \mathrm{a}$ & B $8.8 \mathrm{c}$ & A $42.5 \mathrm{c}$ & A 2377 a & A $2660 \mathrm{~b}$ & A $2435 b$ \\
\hline & UPFA Ouro & C $3.3 a$ & B $41.3 \mathrm{~b}$ & A $91.3 \mathrm{a}$ & A 2768 a & A 2777 b & A 3002 a \\
\hline & Mean & 1.9 & 14.4 & 41.3 & 2524 & 2906 & 2553 \\
\hline \multirow{6}{*}{$\begin{array}{l}\frac{0}{0} \\
\frac{0}{\overline{0}} \\
\overline{0} \\
0 \\
0 \\
0 \\
\omega\end{array}$} & FAEM Carlasul & C $3.8 \mathrm{a}$ & B $82.5 \mathrm{a}$ & A $95.0 \mathrm{a}$ & B 2816 a & A 3243 a & A 3276 a \\
\hline & & C $4.8 \mathrm{a}$ & B 42.5 b & A 95.0 a & A 2474 a & A $2795 b$ & A $2527 b$ \\
\hline & URS Guria & C $1.0 \mathrm{a}$ & B 33.8 b & A $72.5 b$ & B 2620 a & A 3176 a & B 2885 a \\
\hline & IAC 7 & C $4.5 \mathrm{a}$ & B $42.5 \mathrm{~b}$ & A $66.3 \mathrm{~b}$ & A 2408 a & A $2410 b$ & A $2343 b$ \\
\hline & Mean & 3.5 & 50.3 & 82.4 & 2580 & 2906 & 2758 \\
\hline & & \multicolumn{6}{|c|}{2014} \\
\hline \multirow{5}{*}{ 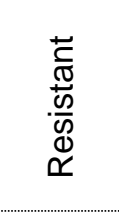 } & Brisasul & B $6.3 \mathrm{c}$ & B 7.5 e & A $25.0 \mathrm{~d}$ & B 1222 a & A 1613 a & A 1529 a \\
\hline & URS Taura & C $6.8 \mathrm{c}$ & B $21.3 d$ & A $48.8 \mathrm{c}$ & A 526 b & A 613 b & A 738 c \\
\hline & URS FapaSlava & B 9.8 C & B $15.0 \mathrm{~d}$ & A $32.5 d$ & B 428 b & A 679 b & A 700 C \\
\hline & UPFA Ouro & C $13.8 \mathrm{~b}$ & B 51.3 C & A $76.3 \mathrm{~b}$ & B 1285 a & A $1543 a$ & A $1560 a$ \\
\hline & Mean & 9.2 & 23.8 & 45.7 & 865 & 1112 & 1132 \\
\hline \multirow{5}{*}{ 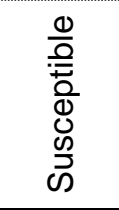 } & FAEM Carlasul & B 22.5 b & A $83.8 \mathrm{a}$ & A 90.0 a & B 1200 a & A 1728 a & A $1522 a$ \\
\hline & URS Corona & C $17.5 \mathrm{~b}$ & B 66.3 b & A 87.5 a & B $1113 a$ & A 1566 a & B 1286 a \\
\hline & URS Guria & B $42.3 \mathrm{a}$ & A $91.3 \mathrm{a}$ & A 95.8 a & B $1141 \mathrm{a}$ & A $1367 a$ & B 999 b \\
\hline & & B $40.0 \mathrm{a}$ & A 91.3 a & A 92.5 a & A 405 b & A 845 b & A 606 c \\
\hline & Mean & 30.6 & 83.1 & 91.5 & 965 & 1377 & 1103 \\
\hline
\end{tabular}

Means followed by the same capital letter in the row and lowercase in the column (within location and year) do not differ from each other by the Scott \& Knott at $\mathrm{P} \leq 0.05 ;+30,90,150=$ nitrogen doses $\left(\mathrm{kg} \mathrm{ha}^{-1}\right)$.

Grain yield expresses a complex quantitative inheritance, usually under high GxE effects, difficulting the identification of high yield potential and predictable cultivars (Vesohoski et al., 2011, Silva et al., 2015). Very high $\mathrm{N}$ doses may not show effective expression in grain yield and to promote extreme vegetative growth, leading to significant losses in grain yield and quality due to lodging (Barraclough et al., 2010, Marolli et al., 2017). The best yields in oats in response to $\mathrm{N}$ fertilizer were obtained when the precipitation was well 
distributed and lower temperatures, when compared to rainier years (Mantai et al., 2015). Therefore, the characterization of performance of available cultivars for recommendation is obtained by yield and lodging in the use of nitrogen under distinct cultivation conditions (Silva et al., 2016, Marolli et al., 2017). In this sense, Arenhardt et al. (2017) point the need for crosses between high yield cultivars, stable and with reduced lodging, for the development of populations for simultaneous selection for these characters.

In Tables 4 and 5, linear equations that describe the performance of cultivars regarding grain yield and lodging, as a function of $\mathrm{N}$ dose $(30,90,150$ $\mathrm{kg} \mathrm{ha}^{-1}$ ), in the estimation of agronomic efficiency and the interpolation of points 60 and $120 \mathrm{~kg} \mathrm{ha}^{-1}$ of this nutrient.

Table 4 - Linear equation in the estimation of the agronomic efficiency and interpolation in the 60 and $120 \mathrm{~kg} \mathrm{ha}{ }^{-1}$ nitrogen points in oat cultivars resistant and susceptible to lodging. Capão do Leão, RS.

\begin{tabular}{|c|c|c|c|c|c|}
\hline Group & Cultivar & $\begin{array}{l}\text { Equation } \\
\left(y= \pm a \pm b_{x}\right)\end{array}$ & $\mathrm{R}^{2}$ & $\begin{array}{c}\text { Interpolation } \\
\mathrm{GY}=\mathrm{a} \pm \mathrm{b}_{60}( \pm 1 \mathrm{DP}) \\
\mathrm{AC}= \pm \mathrm{a} \pm \mathrm{b}_{60}( \pm 0,5 \mathrm{DP})\end{array}$ & $\begin{array}{l}\text { Interpolation } G Y=a \pm b_{120} \\
( \pm 1 D P) \\
A C= \pm a \pm b_{120}( \pm 0,5 D P)\end{array}$ \\
\hline \multirow{5}{*}{ 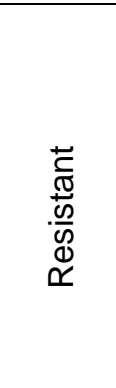 } & Brisasul & $\begin{array}{l}G Y=2484+2.40 x \\
A C=-16.95+0.40 x\end{array}$ & $\begin{array}{l}63.1 \\
83.0\end{array}$ & \begin{tabular}{l}
\multicolumn{1}{c}{2013} \\
$2628( \pm 376.3) \mathrm{S}$ \\
$7.05( \pm 3.3)$
\end{tabular} & $\begin{array}{l}2772( \pm 282.0) \mathbf{S} \\
31.3( \pm 24.2) \mathbf{I}\end{array}$ \\
\hline & URS Taura & $\mathrm{GY}=1544+4.68 \mathrm{x}$ & 99.7 & $1824( \pm 227.0)$ & $2106( \pm 209.1)$ \\
\hline & Uns laura & $L=-0.45+0.07 x$ & 97.2 & $3.75( \pm 3.4) I$ & $7.9( \pm 3.3) I$ \\
\hline & URS FapaSlava & $\begin{array}{l}G Y=1643-1.85 x \\
L=-6.52+0.21 x\end{array}$ & $\begin{array}{l}28.5 \\
79.4\end{array}$ & $\begin{array}{l}1532( \pm 341.7) \mid \\
6.08( \pm 1.5) \mid\end{array}$ & $\begin{array}{l}1421( \pm 440.7) \text { I } \\
18.7( \pm 13.9) \text { I }\end{array}$ \\
\hline & UPFA Ouro & $\begin{array}{l}\mathrm{GY}=2104+3.88 x \\
\mathrm{~L}=-4.6+0.38 x\end{array}$ & $\begin{array}{l}42.3 \\
72.9 \\
\end{array}$ & $\begin{array}{l}2337( \pm 496.0) \\
18.2( \pm 5.6)\end{array}$ & $\begin{array}{l}2570( \pm 347.5) \\
41.0( \pm 25.9)\end{array}$ \\
\hline \multirow{4}{*}{ 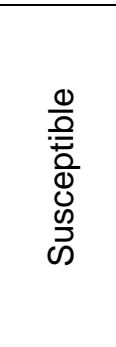 } & FAEM Carlasul & $\begin{array}{l}G Y=2017+4.33 x \\
L=4.10+0.48 x\end{array}$ & $\begin{array}{l}87.2 \\
78.2\end{array}$ & $\begin{array}{l}2277( \pm 237.0) \\
32.9( \pm 30.2)\end{array}$ & $\begin{array}{l}2537( \pm 390.8) \\
61.7( \pm 8.3)\end{array}$ \\
\hline & URS Corona & $\begin{array}{l}\mathrm{GY}=2474+4.23 x \\
\mathrm{~L}=-8.20+0.66 x\end{array}$ & $\begin{array}{l}72.5 \\
99.7\end{array}$ & $\begin{array}{l}2728( \pm 664.5) \mathrm{S} \\
31.4( \pm 24.9)\end{array}$ & $\begin{array}{l}2982( \pm 437.4) \mathrm{S} \\
71.0( \pm 21.5) \mathrm{S}\end{array}$ \\
\hline & URS Guria & $\begin{array}{l}\mathrm{GY}=1875+6.13 x \\
\mathrm{~L}=-4.87+0.62 x\end{array}$ & $\begin{array}{l}70.6 \\
99.8\end{array}$ & $\begin{array}{l}2243( \pm 472.3) \\
32.3( \pm 23.0)\end{array}$ & $\begin{array}{l}2611( \pm 209.7) \\
69.5( \pm 20.9) \mathrm{S}\end{array}$ \\
\hline & IAC 7 & $\begin{array}{l}G Y=1538+1.74 x \\
L=-0.08+0.68 x\end{array}$ & $\begin{array}{l}37.1 \\
93.8\end{array}$ & $\begin{array}{l}1642( \pm 507.8) \text { I } \\
40.7( \pm 32.4) \mathrm{S}\end{array}$ & $\begin{array}{l}1747( \pm 502.7) \mathbf{I} \\
81.5( \pm 12.5) \mathrm{S}\end{array}$ \\
\hline & $\bar{X} G Y( \pm 1 D P)$ & \multicolumn{3}{|c|}{$2151( \pm 415.4)$} & $52.5)$ \\
\hline & $\bar{X} L( \pm 0.5 \mathrm{DP})$ & \multicolumn{3}{|c|}{$21.6( \pm 15.5)$} & 6.3) \\
\hline \multirow{4}{*}{ 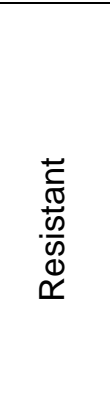 } & Brisasul & $\begin{array}{l}G Y=2371-0.78 x \\
L=6.89+0.19 x\end{array}$ & $\begin{array}{l}44.7 \\
79.0\end{array}$ & $\begin{array}{l}2014 \\
2324( \pm 228.6) \\
18.3( \pm 13.1)\end{array}$ & $\begin{array}{l}2292( \pm 262.8) \\
29.7( \pm 9.6) I\end{array}$ \\
\hline & URS Taura & $\begin{array}{l}G Y=2189+0.92 x \\
L=-0.10+0.34 x\end{array}$ & $\begin{array}{l}90.7 \\
96.4\end{array}$ & $\begin{array}{l}2244( \pm 344.5) \\
20.3( \pm 11.2)\end{array}$ & $\begin{array}{l}2299( \pm 278.2) \\
40.7( \pm 16.5) I\end{array}$ \\
\hline & URS FapaSlava & $\begin{array}{l}G Y=1850+0.70 x \\
L=9.70+0.20 x\end{array}$ & $\begin{array}{l}99.4 \\
44.9\end{array}$ & $\begin{array}{l}1892( \pm 260.6) \\
21.7( \pm 21.2)\end{array}$ & $\begin{array}{l}1934( \pm 256.6) \\
33.7( \pm 12.5) I\end{array}$ \\
\hline & UPFA Ouro & $\begin{array}{l}\mathrm{GY}=1888+5.18 x \\
\mathrm{~L}=23.75+0.21 x\end{array}$ & $\begin{array}{l}98.7 \\
48.1\end{array}$ & $\begin{array}{l}2199( \pm 255.6) \\
36.4( \pm 20.5)\end{array}$ & $\begin{array}{l}2510( \pm 268.4) \\
49.0( \pm 11.3)\end{array}$ \\
\hline \multirow{6}{*}{ 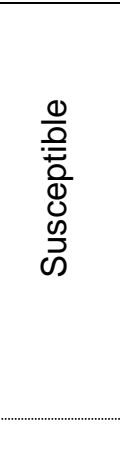 } & FAEM Carlasul & $\begin{array}{l}G Y=2215+1.22 x \\
L=29.79+0.35 x\end{array}$ & $\begin{array}{l}53.4 \\
77.2\end{array}$ & $\begin{array}{l}2288( \pm 246.9) \\
50.8( \pm 24.1)\end{array}$ & $\begin{array}{l}2361( \pm 276.6) \\
71.8( \pm 10.8) \mathrm{S}\end{array}$ \\
\hline & URS Corona & $\begin{array}{l}G Y=2427-0.71 x \\
L=3.00+0.53 x\end{array}$ & $\begin{array}{l}27.4 \\
98.5\end{array}$ & $\begin{array}{l}2384( \pm 316.0) \\
34.8( \pm 14.3)\end{array}$ & $\begin{array}{l}2342( \pm 300.0) \\
66.6( \pm 22.4)\end{array}$ \\
\hline & URS Guria & $\begin{array}{l}G Y=2189+2.28 x \\
L=23.65+0.47 x\end{array}$ & $\begin{array}{l}13.7 \\
71.7\end{array}$ & $\begin{array}{l}2326( \pm 460.7) \\
51.9( \pm 32.5)\end{array}$ & $\begin{array}{l}2463( \pm 537.8) \\
80.1( \pm 6.5) \mathrm{S}\end{array}$ \\
\hline & IAC 7 & $\mathrm{GY}=1439+1.81 \mathrm{x}$ & 15.6 & $1548( \pm 310.3)$ I & $1656( \pm 325.7)$ I \\
\hline & $\bar{X} G Y( \pm 1$ DP $)$ & $L=38.13+0.37 x$ & $\begin{array}{l}90.1 \\
0( \pm 30\end{array}$ & $\begin{array}{r}60.3( \pm 20.7) \mathbf{S} \\
2232( \pm 3\end{array}$ & ${ }_{3.3)}^{82.5( \pm 7.5) \mathrm{S}}$ \\
\hline & $\bar{X} L( \pm 0.5 \mathrm{DP})$ & & $.8( \pm 1 s$ & $56.8( \pm 1$ & \\
\hline
\end{tabular}

$\mathrm{R}^{2}=$ coefficient of determination; $\mathrm{DP}=$ standard deviation; $\mathrm{GY}=$ grain yield $\left(\mathrm{kg} \mathrm{ha}^{-1}\right) ; \mathrm{L}=$ lodging; $\overline{\mathrm{X}}=$ general mean . $\mathbf{S}=$ higher than the average + 1SD in the GY and + 0.5 SD in the $L ; \mathbf{I}=$ lower than the average + 1DP in the GY and + $0.5 \mathrm{SD}$ in the $\mathrm{L}$. 
Table 5 - Linear equation in the estimation of the agronomic efficiency and interpolation at the 60 and $120 \mathrm{~kg} \mathrm{ha}^{-1}$ nitrogen points in oat cultivars resistant and susceptible to lodging. Augusto Pestana, RS.

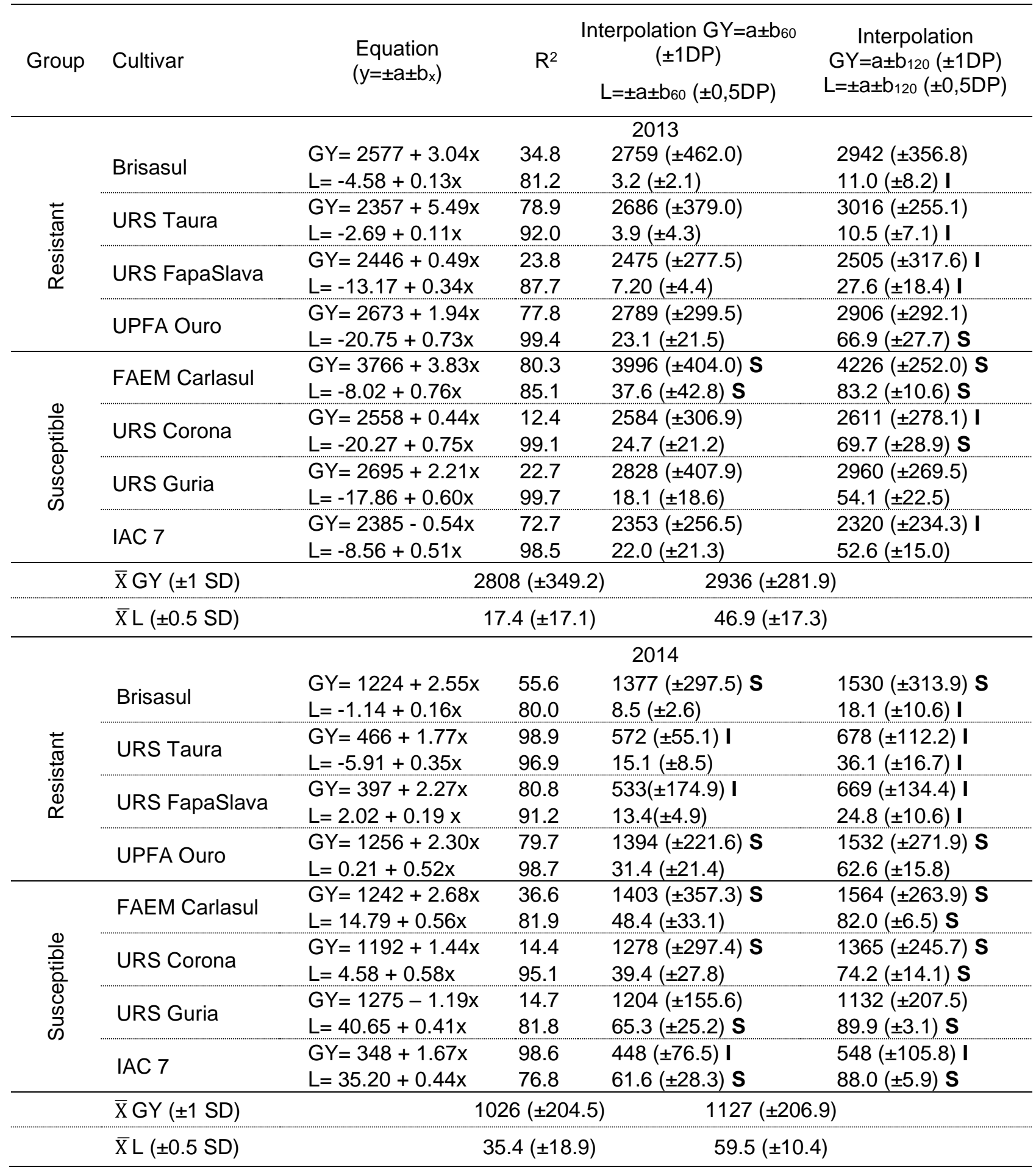

$\mathrm{R}^{2}=$ coefficient of determination; $\mathrm{SD}=$ standard deviation; $\mathrm{GY}=$ grain yield $\left(\mathrm{kg} \mathrm{ha}^{-1}\right) ; \mathrm{L}=$ lodging; $\overline{\mathrm{X}}=$ general mean. $\mathbf{S}=$ higher than the average + 1DP in the GY and + 0.5DP in the $L ; I=$ lower than the average + 1SD in the GY and + 0.5SD in the $L$.

Agronomic efficiency is obtained by the parameter $\left(b_{x}\right)$ from the linear equation, indicating an increase in grain yield per unity of $\mathrm{N}$ supplied. For the correct efficiency analysis of a given cultivar, it is also considered the starting point of performance, given by the analyses of the equation's linear coefficient (a). In Capão do Leão, 2013 (Table 4), the points 60 and
$120 \mathrm{~kg} \mathrm{ha}^{-1}$ of $\mathrm{N}$, for grain yield, indicated superiority (S) of cultivars Brisasul (resistant group) and URS Corona (susceptible group). Among these, the cultivar Brisasul showed a reduced lodging (I) at the very high $\mathrm{N}$ dose. In the resistant group, although the higher agronomic efficiency seems to have been obtained by URS Taura, with $4.68 \mathrm{~kg}$ of grains produced per $\mathrm{kg}$ of 
$\mathrm{N}$ supplied, starts from a highly reduced linear coefficient $\left(1,544 \mathrm{~kg} \mathrm{ha}^{-1}\right)$, leading to reduced final grain yield when compared to the cultivars with lower angular coefficients. Therefore, in the lodging resistant group, the cultivar Brisasul, showed a larger association between the supplied $\mathrm{N}$ and the obtained product, starting from higher linear coefficient means, suggesting higher agronomic efficiency for grain yield as a function of $\mathrm{N}$ use. Among the susceptible group cultivars, URS Corona did perform better, with high angular and linear coefficient as a function of nitrogen.

In Capão do Leão, 2014 (Table 4), none of the cultivars showed superior grain yields. On the other hand, reduced lodging values (I) based on the average + 0.5 standard deviation obtained for the cultivars Brisasul, URS Taura and URS FapaSlava (resistant group), at the interpolation point $120 \mathrm{~kg} \mathrm{ha}^{-1}$. The obtained results point to a strong dependence of nutrient uptake according to the conditions of the agricultural year, with exception of the cultivar UPFA Ouro, with adequate linear coefficient and high angular coefficient in the response of product by the supplied input. This condition raises the hypothesis of the presence of genes that promote higher yield stability under management changes in this cultivar. The higher values of agronomic nitrogen use efficiency on grain yield by the analysis of linear and angular coefficients was obtained for the cultivars UPFA Ouro (resistant) and URS Guria (susceptible). Negative angular coefficients were obtained for the cultivars Brisasul (resistant) and URS Corona (susceptible), showing higher instability in the performance of nutrient use on the others.

In Table 5, in Augusto Pestana 2013, the cultivar FAEM Carlasul (susceptible group) did show a superior grain yield (S), independent from the interpolated points analyzed. In 2014, in unfavorable year, the cultivars FAEM Carlasul and URS Corona (susceptible group); Brisasul and UPFA Ouro (resistant group) did show higher grain yield than the others in the interpolation points. A reduced lodging was detected in the cultivar Brisasul (resistant group). In 2013, FAEM Carlasul displayed the highest linear and angular coefficients under this cultivation condition, confirming a higher agronomic efficiency in the use of nitrogen. Although the cultivar URS Taura had shown a higher angular coefficient, it started at a very low value, not reaching an effective response with increasing $N$ doses. In 2014, the cultivars Brisasul and UPFA Ouro (resistant group) did show similar behavior, displaying the highest linear and angular coefficients. FAEM Carlasul (susceptible group) did show higher agronomic efficiency, with similar efficiency to the best performing cultivars from the susceptible group. In general, either in the most favorable (2013) or unfavorable (2014) year, FAEM Carlasul displayed high agronomic efficiency for $\mathrm{N}$ use efficiency converted to grain yield.

The agronomic efficiency in converting sup- plied nitrogen into biomass and grains was observed for wheat cultivars, suggesting that, in unfavorable years, there was a grain yield increase of $6.7 \mathrm{~kg} \mathrm{ha}^{-1}$ for each $\mathrm{kg}$ of $\mathrm{N}$ added. On the other hand, there was an increase of $19.4 \mathrm{~kg} \mathrm{ha}^{-1}$ for each $\mathrm{kg}$ of $\mathrm{N}$ added (Brezolin et al., 2017). According to Mantai et al. (2016), there is a growing trend regarding the nitrogen use efficiency in converting to biomass in oats, when increasing $\mathrm{N}$ doses are given on top. This is not always true when the conversion is to grain yield. Besides, succession schemes of high and low $\mathrm{N}$-residual release, soybean/oat and maize/oat, respectively, change at a significant way, the agronomic efficiency in $\mathrm{N}$ use. However, climatic elements act on nitrogen use efficiency, generating a direct relationship between meteorological variables and grain yield (Anjos \& Neri, 2005, Benin et al., 2012). Silva et al. (2012) observed interactivity of genetic and environmental effects on the efficiency of nitrogen use and its conversion to grain yield and oat lodging cultivars.

In Tables 6 and 7 regression equations are presented as a function of nitrogen doses with the real and interpolated points (30, 60, 90, 120 and $\left.150 \mathrm{~kg} \mathrm{ha}^{-1}\right)$. Therefore, a second degree equation was fit to estimate the optimal point, defining the maximum technical efficiency of $\mathrm{N}$ use and its conversion to grain yield. In Capão do Leão, 2013 (Table 6), the quadratic fitting of grain yield was observed as a function of nitrogen dose, except for the cultivars URS Taura and FAEM Carlasul, of linear trend. Although the supply of $150 \mathrm{~kg} \mathrm{ha}^{-1}$ represents a very high dose, these cultivars did not reach a maximum point. Besides, even showing similar angular coefficients, FAEM Carlasul displayed superiority of linear coefficient, starting from higher yield means. Regarding lodging expression, a positive linearity was observed for all oat cultivars when the $\mathrm{N}$ doses increased, with a higher angular coefficient in the cultivars from the susceptible group. Although the highest optimal $\mathrm{N}$ dose was obtained for URS Guria (124 kg ha-1) from the susceptible group, the cultivars FAEM Carlasul and URS Corona displayed a lower point of maximum at 90 and $100 \mathrm{~kg}$ of $\mathrm{N} \mathrm{ha}^{-1}$, respectively. These two presented grain yield similar and superior to URS Guria, respectively. Therefore, under this cultivating condition, the cultivars FAEM Carlasul and URS Corona displayed higher technical efficiency of $\mathrm{N}$ use, with the optimal point to the higher grain yield at a lower $\mathrm{N}$ dose. The use of the optimal dose, in all oat cultivars, independing from the lodging phenotype group, did cause high number of lodged plants. In Capão do Leão, 2014 (Table 6), the highest nitrogen use technical efficiency for grain yield was obtained by the cultivars Brisasul $\left(70 \mathrm{~kg} \mathrm{ha}^{-1}\right)$, from the resistant group and FAEM Carlasul (67 kg ha-1) from the susceptible group. With the lowest dose of nitrogen needed to reach the maximum grain yield when compared to the other cultivars. The cultivar IAC 7, in many situations showed the most reduced yields and the cultivar Brisasul, the lowest lodging values at the optimal nitrogen dose. 
Table 6 - Regression equation in estimating the technical efficiency of nitrogen use in oat cultivars resistant and susceptible to lodging, Capão do Leão, RS.

\begin{tabular}{|c|c|c|c|c|c|c|}
\hline Group & Cultivar & $\begin{array}{c}\text { Equation } \\
\left(y= \pm a \pm b x \pm c x^{2}\right)\end{array}$ & $\mathrm{R}^{2}$ & $\begin{array}{c}\mathrm{P}\left(\mathrm{b}_{\mathrm{ix}}\right) \\
\left(\mathrm{b}_{\mathrm{ix}}{ }^{2}\right)\end{array}$ & $\begin{array}{l}\text { Dose N } \\
\left(\mathrm{kg} \mathrm{ha}^{-1}\right)\end{array}$ & $\begin{array}{c}Y_{E} \\
\left(\mathrm{~kg} \mathrm{ha}^{-1}\right) \\
(\%)\end{array}$ \\
\hline \multirow{6}{*}{ 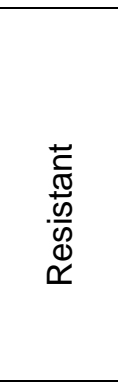 } & Brisasul & $\begin{array}{c}\text { Year 2013 } \\
G Y=2224+9.90 x-0.0416 x^{2} \\
L=-17.275+0.4008 x\end{array}$ & $\begin{array}{l}93 \\
85\end{array}$ & * & $\begin{array}{c}119 \\
(119)\end{array}$ & $\begin{array}{r}2813 \\
30\end{array}$ \\
\hline & URS Taura & $\begin{array}{l}G Y=1544+4.6883 x \\
L=-0.225+0.0691 x\end{array}$ & 99 & * & 90 & $\begin{array}{r}1966 \\
6\end{array}$ \\
\hline & \multirow{2}{*}{ URS FapaSlava } & $\begin{array}{l}L=-0.225+0.0691 x \\
G Y=784+22.976 x-0.1379 x^{2}\end{array}$ & 83 & * & $\frac{(90)}{83}$ & $\begin{array}{r}6 \\
1741\end{array}$ \\
\hline & & $L=-6.82+0.2091 x$ & 82 & * & (83) & 10 \\
\hline & \multirow{2}{*}{ UPFA Ouro } & $G Y=1463+22.406 x-0.1028 x^{2}$ & 89 & * & 109 & 2683 \\
\hline & & $\mathrm{L}=-4.7+0.375 \mathrm{x}$ & 77 & * & $(109)$ & 36 \\
\hline \multirow{8}{*}{ 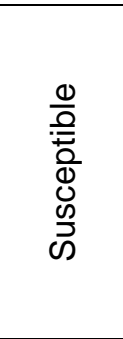 } & \multirow{2}{*}{ FAEM Carlasul } & $G Y=2014+4.3366 x$ & 89 & * & 90 & 2404 \\
\hline & & $\mathrm{L}=5.5+0.475 \mathrm{x}$ & 99 & * & (90) & 48 \\
\hline & \multirow{2}{*}{ URS Corona } & $G Y=1364+36.340 x-0.1783 x^{2}$ & 85 & * & 102 & 3216 \\
\hline & & $L=-8.15+0.6633 x$ & 99 & * & $(102)$ & 59 \\
\hline & \multirow{2}{*}{ URS Guria } & $G Y=1317+22.260 x-0.0896 x^{2}$ & 95 & * & 124 & 2699 \\
\hline & & $L=-4.725+0.6208 x$ & 99 & * & $(124)$ & 72 \\
\hline & \multirow{2}{*}{ IL 7} & $G Y=1219+10.981 x-0.0513 x^{2}$ & 94 & * & 107 & 1806 \\
\hline & & $L=1.375+0.6725 x$ & 95 & * & $(107)$ & 73 \\
\hline \multirow{9}{*}{ 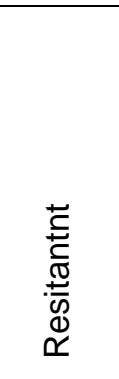 } & \multirow{3}{*}{ Brisasul } & Year 2014 & & & & \\
\hline & & $G Y=2248+2.7666 x-0.0197 x^{2}$ & 90 & * & 70 & 2345 \\
\hline & & $L=7.35+0.1916 x$ & 82 & * & $(70)$ & 21 \\
\hline & \multirow{2}{*}{ URS Taura } & $G Y=2117+3.5175 x-0.0184 x^{2}$ & 76 & * & 96 & 2285 \\
\hline & & $L=-0.65+0.345 x$ & 97 & * & $(96)$ & 32 \\
\hline & \multirow{2}{*}{ URS FapaSlava } & $G Y=1850+0.7016 x$ & 99 & ns & 90 & 1913 \\
\hline & & $L=11.2+0.2016 x$ & 49 & * & $(90)$ & 29 \\
\hline & \multirow{2}{*}{ UPFA Ouro } & $G Y=1889+5.1766 x$ & 99 & * & 90 & 2354 \\
\hline & & $L=25.125+0.2025 x$ & 52 & * & $(90)$ & 43 \\
\hline \multirow{8}{*}{ 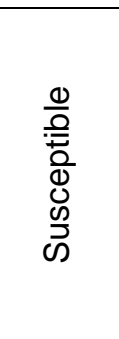 } & \multirow{2}{*}{ FAEM Carlasul } & $G Y=2377-3.464 x+0.0260 x^{2}$ & 93 & * & 67 & 2262 \\
\hline & & $L=30.625+0.3558 x$ & 80 & * & (67) & 54 \\
\hline & \multirow{2}{*}{ URS Corona } & $G Y=2591-5.4803 x+0.0264 x^{2}$ & 87 & * & 104 & 2306 \\
\hline & & $L=2.75+0.5316 x$ & 98 & * & $(104)$ & 58 \\
\hline & \multirow{2}{*}{ URS Guria } & $G Y=3011-21.5128 x+0.1321 x^{2}$ & 84 & * & 81 & 2135 \\
\hline & & $L=25.5+0.46 x$ & 75 & * & $(81)$ & 63 \\
\hline & \multirow{2}{*}{ IAC 7} & $G Y=1793-8.736 x+0.0556 x^{2}$ & 71 & * & 79 & 1449 \\
\hline & & $\mathrm{L}=38.6+0.37 \mathrm{x}$ & 91 & * & $(79)$ & 68 \\
\hline
\end{tabular}

$\mathrm{R}^{2}=$ coefficient of determination; $\mathrm{P}(\mathrm{bix})=$ parameter that measures the slope of the line by the T probability at $5 \%$ error; * and ${ }^{n s}=$ Significant and not significant, respectively, at $5 \%$ probability of error by the $\mathrm{F}$ test; Dose $\mathrm{N}=$ ideal nitrogen dose for each variable; $Y_{E=}$ Estimation of yield and lodging by the ideal dose; $\mathrm{GY}=$ grain yield $\left(\mathrm{kg} \mathrm{ha}^{-1}\right) ; \mathrm{L}=$ lodging $(\%) ;()=$ Consideration of the ideal nitrogen dose for the GY in the calculation of the lodging percentage.

In Augusto Pestana, 2013, all the tested cultivars displayed a quadratic response as a function of $\mathrm{N}$ doses for grain yield with the exception of UPFA Ouro, that although had shown a linear tendency, did not show significant growth (Table 7). Under this condition, the technical efficiency was obtained with the cultivar FAEM Carlasul (102 kg ha-1), showing the highest yield among the cultivars, which had an optimal point at a lower $\mathrm{N}$ dose. On the other hand, the optimal dose in the expression of maximal yield, in the regression equation, showed high lodging. Brisasul showed a satisfactory technical $\mathrm{N}$ use efficiency for grain yield and lodging simulation with the optimal dose, did show the most reduced values of plant fall.
In Augusto Pestana, 2014 (Table 7), a strong reduction in grain yield was observed in the comparison with the previous year, showing higher losses of nitrogen use with low yields, showing a direct costbenefit relationship. The cultivars URS Taura and URS FapaSlava (resistant group), although a linear performance with the increase in nitrogen, growth was nonsignificant. Besides, the strong decrease in grain yield observed for URS Taura, suggests it is very sensitive to low nitrogen supply. A similar behavior was seen for the cultivar IAC 7, from the lodging susceptible group. The best technical efficiency was obtained for the cultivars FAEM Carlasul and URS Corona, from the lodging susceptible group. The simulation of lodging by 
optimal $\mathrm{N}$ dose in these cultivars indicate the occurrence of great harm due to the ease fall of plants. Although the cultivar Brisasul had shown a higher $\mathrm{N}$ need to attain the best grain yields, it did present the lowest lodging values, which can confer na easier harvest and better grain quality. These results point to the necessity of developping more adapted cultivars by breeding programs, bringing higher nitrogen use efficiency, stability and lodging resistance, a decisive condition for advances in the recovery of better adjusted biotypes to the panorama of higher sustainability in agricultural systems.

Table 7 - Regression equation in estimating the technical efficiency of nitrogen use in lodging resistant and susceptible oat cultivars, Augusto Pestana, RS.

\begin{tabular}{|c|c|c|c|c|c|c|}
\hline Group & Cultivar & $\begin{array}{c}\text { Equation } \\
\left(y= \pm a \pm b_{x} \pm c_{x}{ }^{2}\right)\end{array}$ & $\mathrm{R}^{2}$ & $\begin{array}{l}P\left(b_{i x}\right) \\
\left(b_{i x}{ }^{2}\right)\end{array}$ & $\begin{array}{r}\text { Dose N } \\
\left(\mathrm{kg} \mathrm{ha}^{-1}\right)\end{array}$ & $\begin{array}{c}Y_{E} \\
\left(\mathrm{~kg} \mathrm{ha}^{-1}\right) \\
(\%)\end{array}$ \\
\hline \multirow{9}{*}{ 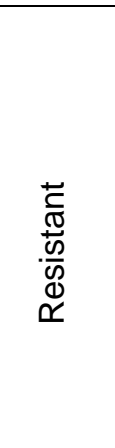 } & \multirow{3}{*}{ Brisasul } & Year 2013 & & & & \\
\hline & & $G Y=1990+19.9981 x-0.0942 x^{2}$ & 88 & * & 106 & 3052 \\
\hline & & $L=-4.675+0.1258 x$ & 85 & * & $(106)$ & 9 \\
\hline & \multirow{2}{*}{ URS Taura } & $G Y=1956+17.0823 x-0.0643 x^{2}$ & 96 & * & 133 & 3090 \\
\hline & & $L=-2.8+0.1116 x$ & 94 & * & (133) & 12 \\
\hline & \multirow{2}{*}{ URS FapaSlava } & $G Y=2101+10.4625 x-0.0554 x^{2}$ & 82 & * & 94 & 2595 \\
\hline & & $L=-13.55+0.3433 x$ & 90 & * & (94) & 19 \\
\hline & \multirow{2}{*}{ UPFA Ouro } & $G Y=2671+1.955 x$ & 81 & ns & 90 & 2847 \\
\hline & & $\mathrm{L}=-20.95+0.7333 x$ & 99 & * & $(90)$ & 45 \\
\hline \multirow{8}{*}{ 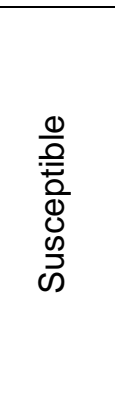 } & \multirow{2}{*}{ FAEM Carlasul } & $G Y=2048+33.0064 x-0.1620 x^{2}$ & 51 & * & 102 & 3729 \\
\hline & & $L=-7.95+0.7633 x$ & 88 & * & (102) & 70 \\
\hline & \multirow{2}{*}{ URS Corona } & $G Y=2158+12.0076 x-0.0642 x^{2}$ & 82 & * & 94 & 2719 \\
\hline & & $L=-20.3+0.7516 x$ & 99 & * & $(94)$ & 50 \\
\hline & \multirow{2}{*}{ URS Guria } & $G Y=2119+18.855 x-0.0925 x^{2}$ & 86 & * & 102 & 3080 \\
\hline & & $L=-17.7+0.595 x$ & 99 & * & (102) & 43 \\
\hline & \multirow{2}{*}{ IAC 7} & $G Y=2411-0.2757 x-0.0014 x^{2}$ & 53 & * & 99 & 2370 \\
\hline & & $L=-8.475+0.5141 x$ & 98 & * & (99) & 42 \\
\hline \multirow{9}{*}{ 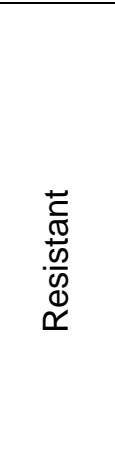 } & \multirow{3}{*}{ Brisasul } & Year 2014 & & & & \\
\hline & & $G Y=611+16.5063 x-0.0703 x^{2}$ & 86 & * & 117 & 1580 \\
\hline & & $L=-0.85+0.16 x$ & 92 & * & (117) & 18 \\
\hline & \multirow{2}{*}{ URS Taura } & $G Y=465+1.7665 x$ & 99 & ns & 90 & 624 \\
\hline & & $L=-6.05+0.35 x$ & 97 & * & $(90)$ & 25 \\
\hline & \multirow{2}{*}{ URS FapaSlava } & $G Y=399+2.2666 x$ & 83 & ns & 90 & 603 \\
\hline & & $L=1.825+0.1908 x$ & 93 & * & $(90)$ & 19 \\
\hline & \multirow{2}{*}{ UPFA Ouro } & $G Y=1092+7.0395 x-0.0263 x^{2}$ & 97 & ns & 134 & 1563 \\
\hline & & $L=0.175+0.552 x$ & 98 & * & (134) & 74 \\
\hline \multirow{8}{*}{$\begin{array}{l}\bar{\Phi} \\
\sum_{\bar{D}} \\
0 \\
心 \\
心\end{array}$} & \multirow{2}{*}{ FAEM Carlasul } & $G Y=743+17.0904 x-0.0800 x^{2}$ & 88 & * & 107 & 1656 \\
\hline & & $L=15.05+0.5633 x$ & 96 & * & (107) & 75 \\
\hline & \multirow{2}{*}{ URS Corona } & $G Y=694+15.8175 x-0.0798 x^{2}$ & 84 & * & 99 & 1477 \\
\hline & & $L=4.9+0.575 x$ & 95 & * & (99) & 62 \\
\hline & \multirow{2}{*}{ URS Guria } & $G Y=872+10.4644 x-0.0647 x^{2}$ & 84 & * & 81 & 1295 \\
\hline & & $L=41.25+0.4108 x$ & 85 & * & (81) & 75 \\
\hline & \multirow{2}{*}{ IAC 7} & $G Y=347+1.67 x$ & 98 & ns & 90 & 497 \\
\hline & & $L=35.85+0.4366 x$ & 98 & * & $(90)$ & 75 \\
\hline
\end{tabular}

$\mathrm{R}^{2}=$ coefficient of determination; $\mathrm{P}(\mathrm{bix})=$ parameter that measures the slope of the line by the probability $\mathrm{T}$ at $5 \%$ error; ${ }^{*}$ and ${ }^{n s}=$ Significant and not significant, respectively, at $5 \%$ probability of error by the $\mathrm{F}$ test; Dose $\mathrm{N}=$ ideal nitrogen dose for each variable; $Y_{E=}$ Estimation of yield and lodging by the ideal dose; $G Y=$ grain yield $\left(\mathrm{kg} \mathrm{ha}^{-1}\right) ; \mathrm{L}=\mathrm{lodging}(\%)$; ()$=$ Consideration of the ideal nitrogen dose for the GY in the calculation of the lodging percentage. 
The $\mathrm{N}$ use efficiency concerns the degree of recovery of this element by plants, considering the losses that generally occurr through leaching in rainy years and by volatilization in dry years (Ma et al., 2010, Silva et al., 2015). Reports on nitrogen use in wheat, showed that plants use only $50 \%$ of the $\mathrm{N}$-fertilizer applied, since half of it is lost due to leaching or volatilization (Dobbelaere \& Croonenborghs, 2002, Gazola et al., 2014). In oats, genetic differences have been observed for the uptake and assimilation of nitrate $\left(\mathrm{NO}_{3}{ }^{-}\right)$and ammonium $\left(\mathrm{NH}_{4}{ }^{+}\right)$, responsible for the consumption of ca. $15 \%$ to $23 \%$ from total carbohydrates fixed by the plant (Golik et al., 2003). Although the best use of fertilizer is dependent of climate conditions and soil cultivation systems, genetic differences among cultivars also influence uptake and $\mathrm{N}$ use rates for biomass and grain formation (Wamser \& Mundstock, 2007: Mantai et al., 2016). Penckowski et al. (2009), reported for wheat that nitrogen use ranging from 90 to $225 \mathrm{~kg} \mathrm{ha}^{-1}$ did not change grain yield under favorable conditions. On the other hand, other reports have indicated better results with $\mathrm{N}$ fertilization and attained a maximum efficiency at 70 up to $120 \mathrm{~kg} \mathrm{ha}^{-1}$, dependending on the cultivar (Espindula et al., 2010, Teixeira Filho et al., 2010). In irrigated wheat, the maximum technical efficiency was obtained with up to $156 \mathrm{~kg} \mathrm{ha}^{-1}$ of $\mathrm{N}$, with grain yield reaching $6,472 \mathrm{~kg} \mathrm{ha}^{-1}$ (Heinemann et al., 2006). In obsolete oat cultivars, Kolchinski \& Schuch (2003) observed the maximum technical $\mathrm{N}$ use efficiency for grain yield when $75 \mathrm{~kg}$ ha $^{-1}$ of $\mathrm{N}$ was used. Silva et al. (2016), studying modern oat cultivars, observed that the maximum technical $\mathrm{N}$ use efficiency is strongly dependent of environmental conditions. These authors report a maximum technical $\mathrm{N}$ use efficiency obtained with $86 \mathrm{~kg} \mathrm{ha}^{-1}$ of $\mathrm{N}$ to reach grain yields of $4,181 \mathrm{~kg} \mathrm{ha}^{-1}$ in a favorable year, and a maximum technical $\mathrm{N}$ use efficiency obtained with $119 \mathrm{~kg} \mathrm{ha}^{-1}$ to reach grain yields of $2,930 \mathrm{~kg} \mathrm{ha}^{-1}$ in an unfavorable year. The wide range of grain yield is associated to the high variability of cultivating conditions, being the factor year the one with the largest influence (Storck et al., 2014). Years with favorable and unfavorable climate change $\mathrm{N}$ availability and its use efficiency, leading to higher yield instability (Espindula et al., 2010, Arenhardt et al., 2015). Also, cultivating systems also influence the technical $\mathrm{N}$ use efficiency (Mantai et al., 2016). Thus, studies focusing on the highest $\mathrm{N}$ use efficiency in recommended cultivars can improve the precision of recommendations and viabilize better fit technologies, economically profitable and with lower environmental impacts, decisive conditions in the quest for a more sustainable agriculture (Parry et al., 2011, Prando et al., 2013).

\section{Conclusions}

When compared to the resistant group, the performance of lodging susceptible oat cultivars shows higher yields at reduced, high and very high $\mathrm{N}$ feritilization, with the exception of the cultivar IAC7.
The cultivars FAEM Carlasul and URS Corona, lodging susceptible, show high technical and agronomical $\mathrm{N}$ use efficiency for grain yield, with high lodging at the ideal $\mathrm{N}$ dose for grain yield.

In general, oat cultivars with higher $\mathrm{N}$ use efficiency to grain yield show higher lodging values.

In the pursue of more ecologically sustainable cultivars, crosses between the cultivars FAEM Carlasul and Brisasul can generate high yield potential populations for the development of nitrogen use efficient and lodging resistant cultivars.

\section{Acknowledgements}

To CNPq, CAPES, FAPERGS, UFPel and UNIJUÍ for grants and science initiation, technological and research productivity fellowships.

\section{References}

Anjos IB, Nery JT (2005) Variáveis meteorológicas associadas ao rendimento de grãos no estado do Paraná. Acta Scientiarum Agronomy 27:133-144.

Arenhardt EG, Silva JAG, Gewehr E, Oliveira AC, Binello MO, Valdiero AC, Goi Neto CJ, Krysczun DK, Cardoso AM, Lima ARC (2015) The nitrogen supply in wheat cultivation dependent on weather conditions and succession system in southern Brazil. African Journal of Agricultural Research 10: 4322-4330.

Arenhardt EG, Silva JAG, Arenhardt LG, Carbonari HP, Oliveira AC (2017) The nitrogen in grain yield and at lodging oat cultivars. International Journal of Current Research 9(01): 45564-45571.

Barraclough PB, Howarth JR, Jones J, Lopez-Bellido R, Parmar S, Shepherd CE, Hawkesford MJ (2010) Nitrogen efficiency of wheat: genotypic and environment variation and prospects for improvement. European Journal of Agronomy 33:1-11.

Benin G, Bornhofen E, Beche E, Pagliosa ES, Silva CL, Pinnow C (2012) Agronomic performance of wheat cultivars in response to nitrogen fertilization levels. Acta Scientiarum Agronomy 34:275-283.

Berry PM, Kendall S, Rutterford Z, Orfor S, Griffiths S (2015) Historical analysis of the effects of breeding on height of winter wheat (Triticum aestivum) and consequences for lodging. Euphytica 1:375-383.

Brezolin AP, Silva JAG, Roos-Frantz F, Binelo MO, Kruger CA, Arenhardt EG, Marolli A, Mantai RD, Scremin OB, Dornelles EF (2017) Wheat yield obtained from nitrogen dose and fractionation. African Journal of Agricultural Research 12(8): 566-76.

Carvalho FIF, Oliveira AC, Valério IP, Benin G, Schmidt DAM, Ribeiro G, Silveira G (2009) Barbarasul: a high-yielding and lodging-resistant white oat cultivar. Crop Breeding and Applied Biotechnology 9:181-186. 
Costa L, Zucareli C, Riede CR (2013) Parcelamento da adubação nitrogenada no desempenho produtivo de genótipos de trigo. Revista Ciência Agronômica 44:215-224.

Cordeiro MB, Dallacort R, Freitas PS, Junior SS, Santi A, Fenner W (2015) Aptidão agroclimática do trigo para as regiões de Rondonópolis, São José do Rio Claro, São Vicente e Tangará da Serra, Mato Grosso, Brasil. Revista Agro@mbiente On-line 9(1):96-101.

Crestani M, Carvalho FIF, Oliveira AC, Silva JAG, Gutkoski LC, Sartori JF, Barbieri RL, Baretta D (2010). Conteúdo de $\beta$-glucana em cultivares de aveia-branca cultivadas em diferentes ambientes. Pesquisa Agropecuária Brasileira 45(3):261-268.

Cruz CD (2013) GENES - a software package for analysis in experimental statistics and quantitative genetics. Acta Scientiarum. Agronomy 35: 271-276.

Dobbelaere S, Croonenborghs A (2002) Effect of inoculation with wild type Azospirillum brasilense an A. irakense strains on development and nitrogen uptake of spring wheat and grain maize. Biology and Fertility of Soils 36:284- 297.

Embrapa (2006) Empresa Brasileira de Pesquisa Agropecuária. Centro Nacional e Pesquisa em Solos. Sistema brasileiro de classificação de solos, Brasília. 306p.

Ercoli L, Masoni A, Pampana S, Mariotti M, Arduini I (2013) As durum wheat productivity is affected by nitrogen fertilisation management in Central Italy. European Journal of Agronomy 44:38-45.

Espindula MC. Rocha VS. Souza MA. Grossi JAS. Souza LT (2010) Doses e formas de aplicação de nitrogênio no desenvolvimento e produção da cultura do trigo. Ciência Agrotécnica 34:1404-1411.

Freo JD, Rosso ND, Moraes LBD, Dias ARG, Elias MC, Gutkoski LC (2011) Physicochemical properties and silicon content in wheat flour treated with diatomaceous earth and conventionally stored. Journal of Stored Products Research 47:316-320.

Flores RA, Urquiaga SS, Alves BJR, Collier LS, Morais RF, Prado RM (2012) Effect of nitrogen fertilizer and cutting age on the dry matter production of elephant grass in Savana. Revista Brasileira Engenharia Agrícola Ambiental 16(12):1282-1288.

Gazola D, Zucareli C, Silva RR, Fonseca ICB (2014) Aplicação foliar de aminoácidos e adubação nitrogenada de cobertura na cultura do milho safrinha. Revista Brasileira Engenharia Agrícola Ambiental 18:700-707.
Golik SI, Chidichimo HO, Pérez D, Pane L (2003) Acumulación, removilización, absorción postantesis y eficiencia de utilización de nitrógeno en trigo bajo diferentes labranzas y fertilizaciones. Pesquisa Agropecuária Brasileira 38:619-626.

Hawerroth MC, Silva JAG, Souza CA, Oliveira AC, Luche HS, Zimmer CM, Hawerroth FJ, Schiavo J, Sponchiado JC (2015). Redução do acamamento em aveia-branca com uso do regulador de crescimento etil-trinexapac. Pesquisa Agropecuária Brasileira 50(2):115-125.

Heinemann $A B$, Stone $L F$, Didonet $A D$, Trindade MG, Soares BB, Moreira JAA, Canovas AD (2006) Eficiência de uso da radiação solar na produtividade de trigo decorrente da adubação nitrogenada. Revista Brasileira de Engenharia Agrícola e Ambiental 10:352-356.

Kolchinski EM, Schuch LOB (2003) Eficiência no uso do nitrogênio por cultivares de aveia branca de acordo com a adubação nitrogenada. Revista Brasileira de Ciência do Solo 27:1033-1038.

Ma BL, Wu TY, Tremblay N, Deen W, Mclaughlin NB, Morrison M, Stewart G (2010) On-farm assessment of the amount and timing of nitrogen fertilizer on ammonia volatilization. Agronomy Journal 102:134-144.

Mandal S, Thangarajan R, Bolan NS, Sarkar B, Khan N, Ok YS, Naidu R (2016) Biochar-induced concomitant decrease in ammonia volatilization and increase in nitrogen use efficiency by wheat. Chemosphere 142:120-7.

Mantai RD, Silva JAG, Arenhardt EG, Heck TG, Sausen ATZR, Krüger CAMB, Cardoso AM, Goi Neto CJ, Krysczun DK (2015) The effect of nitrogen dose on the yield indicators of oats. African Journal of Agricultural Research 10(39):3773-3781.

Mantai RD, Silva JAG, Arenhardt EG, Sausen ATZR, Binello MO, Bianchi V, Silva DR, Bandeira LM (2016). The dynamics of relation oat panicle with grain yield by nitrogen. American Journal of Plant Sciences 7:17-27.

Marangoni MS, Nunes MP, Fonseca Júnior N, Mehta YR (2012) Pyricularia blasto in white oats - a new threat to wheat cultivation. Tropical Plant Pathology 38:198-202.

Marolli A, Silva JAG, Romitti MV, Mantai RD, Scremin OB, Frantz RZ, Sawicki S, Arenhardt EG, Gzergorczick ME, Lima AR (2017) Contributive effect of growth regulator Trinexapac-Ethyl to oats yield in Brazil. African Journal of Agricultural Research 12(10):795-804.

Moes J, Stobbe EH (1991) Barley treated with ethephon: I. yield components and net grain yield. Agronomy Journal 83: 86-90. 
Moll RH, Kamprath EJ, Jackson WA (1982) Analysis and interpretation of factors which contribute to efficiency of nitrogen utilization. Agronomy Journal 74: $562-564$

Parry MAJ, Reynolds M, Salvucci ME, Raines C, Andralojc J (2011) Raising yield potential of wheat. II. Increasing photosynthetic capacity and efficiency. Journal of Experimental Botany 62: 453-467.

Penckowski LH, Zagonel J, Fernandes EC (2009) Nitrogênio e redutor de crescimento em trigo de alta produtividade. Acta Scientiarum Agronomy 31:473479.

Prando AM, Zucarelli C, Fronza V, Oliveira FA, Júnior AO (2013) Características produtivas do trigo em função de fontes e doses de nitrogênio. Pesquisa Agropecuária Tropical 43: 34-41.

Scott AJ, Knott M (1974) A cluster analysis method for grouping means in the analysis of variance. Biometrics 30:507-512.

Silva JAG, Fontaniva C, Costa JSP, Krüger CAMB, Ubessi C, Pinto FB, Arenhardt EG, Gewehr E (2012) Uma proposta na densidade de semeadura de um biotipo atual de cultivares de aveia. Revista Brasileira de Agrociência 18:253-263.

Silva JAG, Arenhardt EG, Krüger CAMB, Lucchese AO, Metz M, Marolli A (2015) A expressão dos componentes de produtividade do trigo pela classe tecnológica e aproveitamento do nitrogênio. Brasileira Engenharia Agrícola Ambiental 19:27-33.
Silva JAG, Goi Neto CJ, Fernandes SB, Mantai RD, Scremin OB, Pretto R (2016) Nitrogen efficiency in oats on grain yield with stability. Revista Brasileira de Engenharia Agrícola e Ambiental 20(12), 1095-1100.

Storck L, Cargnelutti Filho A, Guadagnin JP (2014) Análise conjunta de ensaios de cultivares de milho por classes de interação genótipo $x$ ambiente. Pesquisa Agropecuária Brasileira 49:163-172.

Teixeira Filho MCM, Buzetti S, Andreotti M, Arf O, Benett CGS (2010) Doses, fontes e épocas de aplicação de nitrogênio em trigo irrigado em plantio direto. Pesquisa Agropecuária Brasileira 45:797-804.

Vesohoski F, Marchioro VS, Franco FA, Cantelle A (2011) Componentes do rendimento de grãos em trigo e seus efeitos diretos e indiretos na produtividade. Revista Ceres 58:337-341.

Viola R, Benin G, Cassol LC, Pinnow C, Flores MF, Bornhofen E (2013) Adubação verde e nitrogenada na cultura do trigo em plantio direto. Bragantia 72:90-100.

Wamser AF, Mundstock CM (2007) Adubação nitrogenada em estádios fenológicos em cevada, cultivar "MN 698". Ciência Rural 37:942-948.

Wu W, Huang J, Cui K, Nie L, Wang Q, Yang F, Shah F, Yao F, Peng S (2012) Sheath blight reduces stem breaking resistance and increases lodging susceptibility of rice plants. Field Crops Research 128:101-108. 